\title{
OJED
}

Volume 5, Issue 1 (2020), pp. 100-105

International Journal of

Multidisciplinary Perspectives in Higher Education

ISSN: 2474-2546 Print/ ISSN: 2474-2554 Online

https://ojed.org/jimphe

\section{Flipped Learning During a Global Pandemic: Empowering Students with Choice}

\author{
Rebecca Smith \\ University of Portland, Oregon, USA
}

\begin{abstract}
This essay provides a research brief on current studies related to utilizing a flipped learning model. The flipped model entails students engaging with a recorded lecture prior to live class time, allowing for more student engagement with content, classmates, and the instructor during synchronous class time. A flipped model empowers students with more choice and control over their learning, can improve student achievement, and can reduce student anxiety. During a global pandemic when nearly all higher education institutions have rapidly transitioned to online learning platforms, a flipped model can provide a blended, balanced approach to student learning.
\end{abstract}

Keywords: flipped classroom, online learning, pandemic, student choice

\section{Online learning during a global pandemic}

By April 1, 2020, 90\% of students in the world, including nearly all of the students in U.S. schools were out of school due to the global coronavirus pandemic (Kamenetz, 2020b). The experience of children being out of school for months is unusual, but not unprecedented; the Rwandan genocide, Hurricane Katrina in New Orleans, and fleeing Syrian or Rohingya refugees have also led to a hiatus from face-to-face learning for children. The rapid transition to online learning continues to pose numerous challenges to schools, districts, teachers, students, and parents. Approximately half of students in U.S. public schools are considered to be 
low-income, and 12 million of them lack internet access (Kamenetz, 2020a). The equity challenges that have arisen due to the pandemic reach far beyond technology resources and access, and yet, as teachers, we must utilize instructional methods that can help accommodate for the challenges our students, and we ourselves, are facing.

A flipped learning model for online instruction is one method that individualizes student learning and demonstrates the teacher's value of collaborative synchronous learning time. Many college classes are three hours in duration, and our students frequently have multiple classes per day. Numerous hours on a virtual call can lead to fatigue, caused by the effort to read non-verbal cues, the stress of feeling watched by others, and feelings of vulnerability that can result when our professional and personal spaces are blended (Jiang, 2020). The amount of time we spend on screens can cause physical and mental health impacts, including eye and neck strain, anxiety, depression, and obesity (Andrews, 2020; American Heart Association, 2018). Despite the recommendations from the American Heart Association (2018) to limit screen time to one to two hours per day, since the Coronavirus forced schools and nearly all of life online, screen time for adults and children alike has increased dramatically. A 2019 digital report (Kemp, 2019) found the average adults spent nearly seven hours on mobile devices or online per day, and since the Corona virus pandemic transitioned much of life and learning online, there has been an increase in screen time (Andrews, 2020).

Despite the challenges associated with increased screen time, Covid-19 has led teachers and students alike to learning in virtual spaces. By the end of May 2020, 4,234 higher education institutions and an estimated 25,798,790 students had been impacted by Covid-19 (Entangled Solutions, 2020). Colleges and universities that had previously offered little online learning options were suddenly transitioned into e-learning institutions. Professors with a wide variety of technology competence had to quickly adjust to teaching virtually. A blended approach to online learning though a flipped classroom model allows instructors to integrate synchronous and asynchronous platforms into their classrooms, maintain control of the lecture component of their classes, and provide students with a healthier and more differentiated approach to online learning.

\section{Research on flipped learning}

A flipped classroom model is a flexible pedagogy (Gordon, 2014) housed in the blended learning umbrella of online, or e-learning. In a flipped classroom, the instructor provides web-based lectures for students to view prior to class (Thai et al., 2017). With this content-based instruction occurring prior to a live class session, the professor and classmates can actively engage with difficult cognitive tasks in real time, applying the foundational content they have learned prior to class (Talbert, 2017). 
Students are able to apply concepts and creatively engage with each other in a live learning space (Flipped Learning Network, 2014). The Flipped Learning Network (2014) defined flipped learning within four pillars utilizing the FLIP acronym: 1) Flexible learning environment, which allows students to differentiate and individualize learning; 2) Learning culture, where the learning process is learner-centered; 3) Intentional content, where the professor explicitly connects the learning targets to content and uses differentiated materials; and 4) Professional educator, where the instructor is prepared, knows their students' needs, conducts formative assessments, and is a reflective practitioner. The flipped approach is worth considering in the midst of the current challenges in education and the world.

\section{Benefits of using a flipped model}

Research over the past 10 years has included empirical studies regarding the impact of flipped learning on students. Several studies have found improved academic performance in flipped classroom models (i.e., Albert \& Beatty, 2014; O'Flaherty \& Phillips, 2015; Thai et al., 2017). It appears that flipped classroom learning has a positive impact on academic outcomes as compared to traditional learning models (Thai et al., 2017). Additionally, flipped classrooms have been found to reduce dropout rates and improve exam marks (Lopez-Perez et al., 2011). Gaughan (2014) found that students in a flipped learning environment were better prepared to engage in face-to-face learning, such as debates, discussions, and activities.

The reduced amount of direct, virtual instruction required when students engage with content prior to a live class session also appears to have broader mental health benefits for students. Perhaps one of the most important potential benefits during global pandemic is reduced student anxiety (Aş1ksoy \& Sorakin, 2018). A recent Center for Disease Control and Prevention survey of 5,412 U.S. adults found increased depression and anxiety compared to the previous year, with nearly 25 percent of adults between the ages of $18-24$ reporting that they had "seriously considered" suicide in the past 30 days (Czeisler et al., 2020). Reduced synchronous learning time on a virtual screen can potentially improve the mental health of our students.

In a related finding, Karaca and Ocak (2017) found that flipped learning reduced student cognitive load. Talbert (2017) also found that flipped learning promoted self-regulation in students in their capacity to determine how they digested lecture material in their own time and space. A flipped approach to teaching and learning appears to improve student and staff satisfaction (O'Flaherty \& Phillips, 2015). These academic and health benefits for students are perhaps more important now more than ever. Teachers must accommodate for these challenging times and adjust instructional strategies to meet the needs of students. 


\section{Challenges \& recommendations}

Despite the apparent benefits to a flipped learning model, there are also challenges. There is a large time commitment required of the instructor, and there is a need for institutional support and flexibility with assessments (Wanner \& Palmer, 2015). Additionally, O'Flaherty and Phillips (2015) found little evidence that flipped learning contributed to lifelong learning and the increase in $21^{\text {st }}$ century skills in college students. Perhaps learning from the voices of practitioners who have utilized this model effectively can help improve efficacy. Several recommendations can help promote a successful flipped learning environment, including determining methods for holding students accountable for their individualized learning, such as formative assessments, deliberately choosing what content you want to flip, and asking for feedback from students (Ramirez, 2019). Additionally, using existing video lectures from platforms such as Khan Academy, asking students to listen to podcasts or watch TED Talks in lieu of an instructor created video lecture can reduce the teaching load while diversifying content.

\section{Empower students with choice}

The coronavirus has led to a lack of choice in all parts of life, including how we access education. Flipped learning is one way to provide students with choice, which they value (Wanner \& Palmer, 2015). Flipped classrooms provide a flexible, student-focused approach to online learning (Gordon, 2014). The flipped learning model promotes student autonomy and control over their own learning (Gasparini, 2020). Additionally, a flipped learning environment allows for direct instruction to occur in a student's individual space where students have control and feel safe; active learning occurs in a group space, where students can engage with their peers and instructor in real time (Talbert, 2017). In a world that is steeped in a global pandemic, we often feel lonely, isolated, and socially disconnected. A flipped classroom model can provide students with some control over their learning in a world that currently feels quite out of control.

\section{References}

Aş1ksoy, G., \& Sorakin, A. (2018). The effects of clicker-aided flipped classroom model on learning achievement, physics anxiety and student' perceptions. International Online Journal of Education and Teaching, 5(2), 334-346. Retrieved from https://doaj.org/article/06b7d717efd0466a84fe5a1ce2888414

Albert, M., \& Beatty, B. (2014). Flipping the classroom applications to curriculum redesign for an introduction to management course: Impact on grades. Journal of Education for Business, 89(8), 419424. https://doi.org/10.1080/08832323.2014.929559 
Andrews, T. M. (2020, March 24). Our iPhone weekly screen time reports are through the roof, and people are 'horrified'. Washington Post. https://www.washingtonpost.com/technology/2020/03/24/screentime-iphone-coronavirus-quarantine-covid/

American Heart Association News. (2018, August 6). Limit screen time among kids, experts caution. https://www.heart.org/en/news/2018/08/06/limit-screen-timeamong-kids-experts-caution

Czeisler, M.E., Lane, R. I., Petrosky, E. et al. (2020, August 13). Mental health, substance use, and suicidal ideation during the COVID-19 pandemic - United States, June 24-30, 2020. Center for Disease Control and Prevention. Retrieved September 15, 2020, from https://www.cdc.gov/mmwr/volumes/69/wr/mm6932a1.htm

Flipped Learning Network. (2014). https://flippedlearning.org/definition-offlipped-learning/

Gaughan, J. E. (2014). The flipped classroom in World History. The History Teacher, 47(2), 221-244.

Gasparini, S. (2020). Design and assessment of flipped instruction: A study of student learning and perceptions in higher education.Form@reOpen Journal per la formazione in rete, 20(1), 220-236.

Gordon, N. (2014). Flexible pedagogies: Technology-enhanced learning. The Higher Education Academy, 1-24.

Jiang, M. (2020, April 22). Video chat is helping us stay employed and connected. But what makes it so tiring - and how can we reduce 'Zoom fatigue'? British Broadcasting Corporation (BBC). https://www.bbc.com/worklife/article/20200421-why-zoom-videochats-are-so-exhausting

Kamenetz, A. (2020a, March 26). The biggest distance-learning experiment in history: Week one. National Public Radio. https://www.npr.org/2020/03/26/821921575/the-biggest-distancelearning-experiment-in-history-week-one

Kamenetz, A. (2020b, April 1). What do students need to recover when school closes for months? National Public Radio. https://www.npr.org/2020/04/01/825056995/what-do-students-needto-recover-when-school-closes-for-months

Karaca, C., \& Ocak, M. (2017). Effect of flipped learning on cognitive load: A higher education research. Journal of Learning and Teaching in Digital Age, 2(1), 20-27.

Kemp, S. (2019, Jan. 30) Digital trends 2019: Every single stat you need to know about the internet. https://thenextweb.com/contributors/2019/01/30/digital-trends2019-every-single-stat-you-need-to-know-about-the-internet/

Lopez-Perez, M. V., Perez-Lopez, M. C., \& Rodriguez-Ariza, L. (2011). Blended learning in higher education: Students' perceptions and 
their relation to outcomes. (Report). Computers \& Education, 56(3), 818-826. https://doi.org/10.1016/j.compedu.2010.10.023

O'Flaherty, J., \& Phillips, C. (2015). The use of flipped classrooms in higher education: A scoping review. The Internet and Higher Education, $25,85-95$.

Ramirez, M. (2019, April). Steps for planning my flipped lessons. Flipped Learning Network. https://flippedlearning.org/syndicated/steps-forplanning-my-flipped-lessons/

Talbert, R. (2017). Flipped learning: A guide for faculty teaching face-toface, online, and hybrid courses https://ebookcentral.proquest.com

Thai, N., De Wever, B., \& Valcke, M. (2017). The impact of a flipped classroom design on learning performance in higher education: Looking for the best "blend" of lectures and guiding questions with feedback. Computers \& Education, 107, 113-126.

Wanner, T., \& Palmer, E. (2015). Personalising learning: Exploring student and teacher perceptions about flexible learning and assessment in a flipped university course. Computers \& Education, 88, 354.

\footnotetext{
Author Bio

REBECCA SMITH, Ed.D., is an Assistant Professor in the School of Education at the University of Portland. Her research interests include teacher learning and professional development, culturally responsive practices, and innovative technologies. Email: smithre@up.edu
} 